\title{
Study on airborne fungal diversity in Kokrajhar Science College Campus, Assam, India
}

\author{
Junuwara Almina ${ }^{1}$, Miniswrang Basumatary ${ }^{2}$, Suraj Kumar Nath ${ }^{3}$ \\ and Mohesh Gogoi ${ }^{1,2}$ \\ ${ }^{1}$ Department of Botany, Science College, Kokrajhar, BTC, Assam, India \\ ${ }^{2}$ Institutional Biotech Hub, Science College, Kokrajhar, BTC, Assam, India \\ ${ }^{3}$ Department of Botany, Bodoland University, Kokrajhar, BTC, Assam, India
}

*Corresponding Author: mohesh.gogoi@ rediffmail.com

[Accepted: 21 June 2019]

\begin{abstract}
The present study deals with an investigation on the distribution of airborne fungi within Science College campus, Kokrajhar that has been conducted during 2018. The airborne fungal colonies were isolated through the settle plate method and studied. Total 117 airborne fungal colonies were isolated, of which 20 species belonging to 6 Classes and 9 genera could be identified in the study. Among them, Curvularia species were found the most prevalent in the college campus followed by Pythium, Penicillium, Rhizopus, Botrytis and Geotrichum in the month of May. In August, Aspergillus species was found to be highest followed by Curvularia, Penicillium, Rhizopus and Paecilomyces and Trichoderma respectively. Conspicuously Curvularia and Aspergillus were more abundant in both the indoor and outdoor environment of the college campus in May and August respectively.
\end{abstract}

Keywords: Airborne - Fungi - Aeroallergen - Diversity.

[Cite as: Almina J, Basumatary M, Nath SK \& Gogoi M (2019) Study on airborne fungal diversity in Kokrajhar Science College Campus, Assam, India. Tropical Plant Research 6(2): 171-175]

\section{INTRODUCTION}

Assessing fungal microflora diversity in a place through proper investigation is prerequisite to understand the availability of both harmful and beneficial species in relation to human health. Moreover, it is also important to know the distribution of fungal species in the air, its association with human health problems and the quality of air. The fungal spores are known as environmental bio-particles causing allergic manifestation in human beings. Some certain airborne fungi are pathogenic that causes serious diseases in both plants and animals. Plants and animals including human have varied sensitivity to the airborne fungi, and the sensitivity causes different levels of allergic reaction when come in contact with fungal spore. The distribution of airborne fungi is very unpredictable although some studies reported the regional distribution patterns of microorganisms in soil and water (Green et al. 2004). Fungal spores are ubiquitous in the earth's atmosphere (Bowers et al. 2009). Meanwhile, environmental factors like humidity and wind speed affect the distribution and release of spores (Nielsen 2003). Indoor environments are potential sources of fungal spores and harmful organic compounds such as mycotoxins which can be harmful to human health (Cabral 2010).

Although air is the primary medium for the dispersal of microorganisms, the study on the distribution of airborne fungi has not been done to that extent. Several studies have shown that a wide range of micro-fungi are present in air and water supplies etc. (Pakshir et al. 2007, Hedayati et al. 2011). The recent studies done by Bowers et al. (2013), Cao et al. (2014) etc. has indicated that specific fungal spores are linked with the occurrence of public health problems. Several studies were being carried out to investigate the diversity of fungi in places viz. hospitals, educational settings, industrial sites etc. of various parts of Assam, India. However, in our region, such studies have not been done yet and no such evidence was found. In the present study, the college campus was selected as it is a hub for more than 1500 students. Moreover, it is situated in low land surrounded by the moist place that makes a favorable ground for a number of microorganisms. The identification of fungal microflora can help us to find the problems associated with allergy, respiratory diseases, 
fungal infections in a particular environment like school \& colleges, hospitals, industries and home. In the present study, an attempt has been made to investigate the distribution of airborne fungi and to identify the prevalent fungal species within the campus and to understand the cause of various health issues related to fungi. Such a study is of great concern to evaluate the potential health hazards of allergenic and toxigenic fungi and to make a database of distribution of airborne fungi in a particular area.

\section{MATERIALS AND METHODS}

Study area

The Kokrajhar Science College is located in the western part of Kokrajhar town approximately 500 meters away (Fig. 1). The campus covers an area of 4.5 Acres and it is situated in the eastern part of the Gaurang River in between $26^{\circ} 24^{\prime} \mathrm{N}$ latitude and $90^{\circ} 15^{\prime} \mathrm{E}$ longitude, at an average elevation of 30-45 meters above mean sea level. The campus is bounded by human settlement urban villages in the East and South, Dotma-Kokrajhar road in the West and Paddy field with human settlement in the North. The area is characterized by almost plain topography with sparse vegetation. The average temperature ranges from minimum $15^{\circ} \mathrm{C}$ to maximum $35^{\circ} \mathrm{C}$ throughout the year. The average humidity remains almost the same with variation from $62 \%$ in winter to $87 \%$ in the post-monsoon period. The average annual rainfall of the district is $3102.4 \mathrm{~mm}$ with 110 annual average rainy days. The maximum rainfall occurs during the period from April to August.
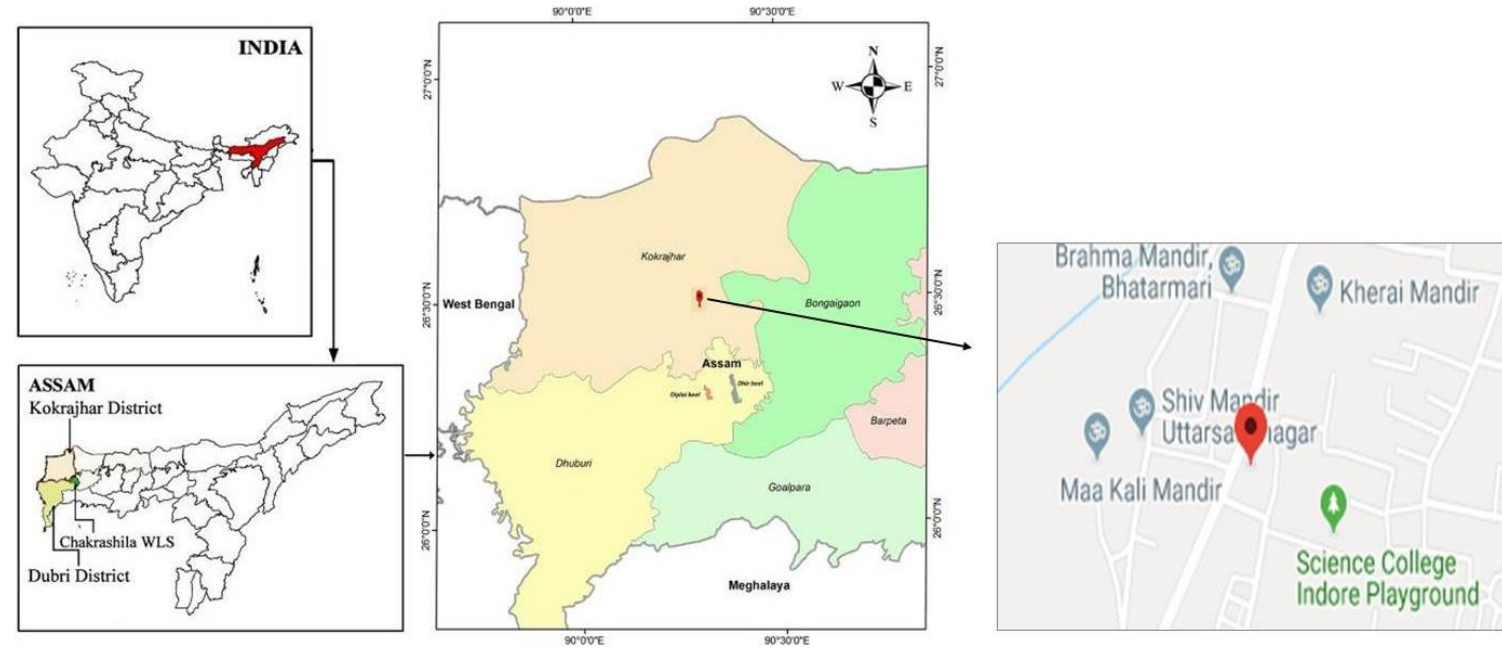

Figure 1. Map showing the location of the study area.

\section{Methodology}

The isolation of the airborne microflora was done through the settle plate method using PDA media. First the Potato dextrose agar (PDA) media was prepared and aseptically poured into petridishes and allowed to solidify; these were then exposed in air at 1.5 meter height for 15 minutes in 5 different locations Site-1 (Backside of college campus), Site-2 (Botanical Garden), Site-3 (Auditorium), Site-4 (Classroom), Site-5 (Central Library) of the college campus. After exposure for 15 minutes, the petridishes were collected and incubated at $28^{\circ} \pm 2^{\circ} \mathrm{C}$ for 3-5 days. Thereafter, colonies grown were counted in each petridish and their mean was considered. Subcultures were also done for some species for better observation of the individual characteristics. The fungal colonies were identified with the help of authentic literature and by comparing the morphological (color, texture, shape, diameter appearance of colony) and microscopic characteristics (reproductive structures, conidia structure along with conidiophores size, shape and mycelium structure). Microphotography was done by using LABOMED Lx 400 microscope at IBT hub laboratory, Science College, Kokrajhar. The lacto phenol and aniline blue wet mount preparation was used for staining and observing under microscope.

\section{RESULTS}

A total of 117 colonies belonging to 9 different fungal genera were isolated (Table 1). The highest number of airborne fungal colonies were found in Site-3 (Auditorium=40) followed by Site-2 (Botanical Garden=32), Site5 (Central Library=18), Site-1 (Backside of college campus=15), and Site-4 (Classroom=12) respectively. From 5 sources of the sample, the Culvularia was found to be most prevalent accounting $41.37 \%$ of the total spore in May and 28.56\% in August (Table $2 \& 3$ ). The airborne fungus of the genus Aspergillus was most encountered with a relative prevalence in terms of isolation equal to $45.71 \%$, followed by Curvularia (28.56\%), Penicillium (14.29\%), Rhizopus (5.71\%), Trichoderma (2.86\%) and Peicilomyces (2.86\%) respectively in the month of August (Table 3). Total fungal concentration in indoor environment was (10 cfu/plate/15min) in May and (13 www.tropicalplantresearch.com 
cfu/plate/15min) in August. In the case of the outdoor environment, the colony forming unit was 11 cfu/plate/15min in the month of May and $12 \mathrm{cfu} /$ plate/15min in the month of August (Table 1). Both temperature and humidity were high during the study period. The study indicates that the outdoor and indoor air of the college campus harbor variety of pathogenic and allergenic airborne fungal spores that may serve as the main source of contamination in indoor environments of the campus viz. auditorium, library, offices, classrooms, etc. The Curvularia species was observed to be the most common fungi isolated from both indoor and outdoor air of different sites of the college campus (Table $2 \& 3$ ). The indoor air of Site-3 had the highest fungal population and Site-4 having the least population (Table 1). Curvularia $(41.37 \%$ ) was the most prevalent isolated fungus followed by Pythium (31.04\%), Penicillum (10.34\%) and Rhizopus (10.34\%) that reflects the findings of Fernstrom \& Goldblatt (2013) who reported these species to be the permanent outdoor air flora (Table 2). Botrytis cinerea is known as the fungal air species in an outdoor environment that account for $3.45 \%$ of the total fungal species in the month of May (Table 2). Common fungal species in air include Aspergillus flavus, A. fumigatus, A. niger, Penicillum notatum, P. chrysogenum (Li \& Kendrick 1995). The airborne fungi Curvularia, Geotrichum, Aspergillus and Penicillium were revealed to be associated with various common health problems. The prevalence of such aeroallergens fungi may due to the influence of favorable ecological conditions inside the college campus. Besides their allergic nature, some are non-allergic and beneficial and they can be used for various purpose like producing antibiotics, enzymes production, biodegradation process and even as biological controlled agents (Shen et al. 2001).

Table 1. Number of colonies grown in the cultured medium exposed in the air of different sites of the college campus in two different months.

\begin{tabular}{lrrr}
\hline \multirow{2}{*}{ Sites } & \multicolumn{4}{c}{ Number of colonies (cfu/plate/15min) } \\
\cline { 2 - 4 } & May & August & Total \\
\hline Site-1 & 08 & 07 & 15 \\
Site-2 & 17 & 15 & 32 \\
Site-3 & 21 & 19 & 40 \\
Site-4 & 02 & 10 & 12 \\
Site-5 & 07 & 11 & 18 \\
\hline \multicolumn{1}{r}{ Total } & $\mathbf{5 5}$ & $\mathbf{6 2}$ & $\mathbf{1 1 7}$ \\
\hline
\end{tabular}

Table 2. Occurrence of airborne fungi in different sites of the college campus in the month of May.

\begin{tabular}{|c|c|c|c|c|c|c|c|}
\hline \multirow{2}{*}{\multicolumn{2}{|c|}{ S.N. Identified species }} & \multicolumn{5}{|c|}{ Number of identified colonies } & \multirow{2}{*}{$\begin{array}{r}\text { Total spore } \\
\text { load }(\%)\end{array}$} \\
\hline & & \multirow{2}{*}{$\begin{array}{r}\text { Site 1 } \\
2\end{array}$} & \multirow{2}{*}{$\begin{array}{r}\text { Site } 2 \\
3\end{array}$} & \multirow{2}{*}{$\begin{array}{r}\text { Site } 3 \\
4\end{array}$} & \multirow{2}{*}{$\begin{array}{r}\text { Site } 4 \\
0\end{array}$} & \multirow{2}{*}{$\begin{array}{r}\text { Site } 5 \\
0\end{array}$} & \\
\hline 1 & Curvularia lunata (Wakker) Boedijn & & & & & & $09(31.03 \%)$ \\
\hline 2 & Carvularia sp. & 0 & 1 & 2 & 0 & 0 & $03(10.34 \%)$ \\
\hline 3 & Pythium aphanidermatum (Edson) Fitzp. & 1 & 1 & 2 & 0 & 0 & $04(13.79 \%)$ \\
\hline 4 & Pythium insidiosum De cock & 0 & 1 & 1 & 0 & 0 & $02(06.90 \%)$ \\
\hline 5 & Pythium diclinum Takunaga & 1 & 0 & 0 & 0 & 1 & $02(06.90 \%)$ \\
\hline 6 & Pythium sp. & 0 & 0 & 1 & 0 & 0 & $01(03.45 \%)$ \\
\hline 7 & Penicillium chrysogenum Thom & 0 & 2 & 0 & 1 & 0 & $03(10.34 \%)$ \\
\hline 8 & Rhizopus oryzae Went \& Prins. Geerl. & 1 & 0 & 0 & 0 & 2 & $03(10.34 \%)$ \\
\hline 9 & Botrytis cinerea Michelle S. Oliveira & 0 & 0 & 1 & 0 & 0 & $01(03.45 \%)$ \\
\hline 10 & Geotrichum candidum Link & 0 & 0 & 1 & 0 & 0 & $01(03.45 \%)$ \\
\hline & Total & 05 & 08 & 12 & 01 & 03 & $29(100 \%)$ \\
\hline
\end{tabular}

Table 3. Occurrence of airborne fungi in different sites of the college campus in the month of August.

\begin{tabular}{|c|c|c|c|c|c|c|c|}
\hline \multirow{2}{*}{ S.N. } & \multirow{2}{*}{ Identified species } & \multicolumn{5}{|c|}{ Number of identified colonies } & \multirow{2}{*}{$\begin{array}{r}\text { Total spore } \\
\text { load }(\%)\end{array}$} \\
\hline & & Site 1 & Site 2 & Site 3 & Site 4 & Site 5 & \\
\hline 1 & Aspergillus niger Van Tieghem & 0 & 2 & 2 & 0 & 2 & $06(17.14 \%)$ \\
\hline 2 & Aspergillus flavus Link & 1 & 2 & 1 & 1 & 0 & $05(14.29 \%)$ \\
\hline 3 & Aspergillus sp. & 0 & 1 & 0 & 0 & 1 & $03(08.57 \%)$ \\
\hline 4 & Aspergillus fumigatus Fresen. & 0 & 0 & 2 & 0 & 0 & $02(05.71 \%)$ \\
\hline 5 & Curvularia lunata (Wakker) Boedijn & 3 & 2 & 0 & 2 & 1 & $08(22.85 \%)$ \\
\hline 6 & Curvularia oryzae Bugnic. & 1 & 1 & 0 & 1 & 0 & $02(05.71 \%)$ \\
\hline 7 & Penicillum notatum Thom & 1 & 0 & 3 & 0 & 1 & $05(14.29 \%)$ \\
\hline 8 & Rhyzopus oryzae Went \& HC Prinsen Geerlings & 0 & 0 & 1 & 1 & 0 & $02(05.71 \%)$ \\
\hline 9 & Trichoderma viridi Pers. & 0 & 0 & 1 & 0 & 0 & $01(02.86 \%)$ \\
\hline \multirow[t]{2}{*}{10} & Peicilomyces lilacenus (Thom) Samson & 0 & 0 & 1 & 0 & 0 & $01(02.86 \%)$ \\
\hline & (2) & 06 & 08 & 11 & 05 & 05 & $35(100 \%)$ \\
\hline
\end{tabular}




\section{DISCUSSION}

The study on airborne fungi has attained maximum importance due to their ubiquitous nature of existence and the increase of allergies and infection caused by them (Larsen \& Gravesen 1991). Globally, more than 180 genera of fungi are associated with allergies and serious human infections (Horner et al. 2004). It has also been reported that micro-fungi cause allergies, spoilage of foods and many other adverse effects and some may even produce mycotoxins that can adversely affect human and animal health (Burge \& Rogers 2000). So, indoor and outdoor airborne fungal spore monitoring in the college campus may be very useful in future from the allergological point of view. Isolation and identification of airborne fungi are of great importance to find the causes associated with the minor health problem in a particular working environment. This can be achieved by isolation and identification of disease causal agents on appropriate culture media.

The microfungi can live in extreme conditions in almost all places and regions. The airborne fungi such as Aspergillus, Penicillium etc. are causative agents of fungal allergies (de Ana et al. 2006). Besides causing allergies, the Aspergillus species are also responsible for mycotoxin production (Nielsen 2003). Aspergillus and Penicillium spores are the most widespread aeroallergens in the world (Asan et al. 2003). Aspergillus fumigatus, A. niger, Penicillium notatum and $P$. chrysogenum identified in our study are also observed to be widespread in the campus that implies the findings of Asan et al. (2003). Fungal concentrations, in the indoor environment of the campus, were high in the library and auditorium this may be due to the presence of paper, house dust etc. As per the cases of health issues reported by the college community, it can be inferred that the airborne fungi Aspergillus, Curvularia and Penicillium are responsible for health issues like skin irritation, eye infection, allergy, asthma etc. Moreover, Trichoderma viride species also found in the campus accounting $2.86 \%$ of the total spore load in August which is beneficial to be used as biocontrol agent having the capacity to inhibit mycelial growth of other fungi plant pathogen such as Sclerotium rolfsii (Basumatary et al. 2015). This species can be tested as a biological control agent against some fungal diseases. Furthermore, some isolated species were also found to be utilized in beneficial ways such as Curvularia lunata is used as antimicrobial agents (Avinash et al. 2015), Penicillium species are used to produce different kinds of antibiotics and pectinase enzyme (Banu et al. 2010) and Rhizopus species are used for the production of Lactic acid from renewable organic materials (Zhang et al. 2007) and Pythium is used as biological control agent for their rapid germination of sporangia (Whipps \& Lumsden 2008).

The wide distribution of airborne fungi may be due to multiple factors which account for dispersal of fungal spores into the air and water at the same time. The fungi available in the air mainly originate from soil, plants and water. Fungal spores in aquatic environments may be transferred to the air by wave action. Their distribution is related to wind, humidity, temperature, rainfall, altitude, vegetation, and some specific reservoirs of contamination (Asan et al. 2003). Relative humidity was consistently less than 70\% in May that increased to $80 \%$ in August that makes the environment more prevalent of fungal spores load in August. Both Curvularia and Phytium were more abundant in the outdoor environment this implies that these fungi enter houses from outside. Spore percentage of Aspergillus was highest in August whereas the species not encountered in the month of May. A positive correlation was observed for the concentration of airborne fungi with humidity in both indoor and outdoor environment.

\section{CONCLUSION}

The fungal species Aspergillus flavus, A. fumigatus, A. niger, Penicillium notatum, P. chrysogenum, Carvularia sp. identified in the present study are aeroallergens and may cause infections. Some of them are nonpathogenic and have the potential to be utilized as biotic resource for other purposes such as antibiotic, enzyme production and biodegradation of waste materials. The study generated a database about the distribution and composition of airborne microflora within the college campus that will be beneficial for future use since no such studies was being conducted earlier. A detailed study is required to evaluate the total microbial diversity of the campus as microbes are ubiquitous in nature. And their availability also varies as per the season, so continuous season wise study is recommended for complete evaluations of fungus species present in the college campus.

\section{ACKNOWLEDGMENTS}

Authors are thankful to the Department of Biotechnology, Govt. of India for providing financial assistance by sanctioning Institutional Level Biotech Hub, Science College, Kokrajhar. Thanks are due to the Principal, Science College, Kokrajhar for his constant support. We also express our thanks to Dr. Sufian Ahmed Tapadar, Faculty, Dept. of Botany, University of Science and Technology, Meghalaya, and Faculties of Botany Department, Science College, Kokrajhar who have extended their cooperation and support during the study. 


\section{REFERENCES}

Asan A, Kirgiz T, Sen B, Camur-elipek B, Guner U \& Guher H (2003) Isolation, identification and seasonal distrubution of airborne and waterborne fungi in Terkos Lake (Istanbul-Turkey). Journal of Basic Microbiology 43(2): 83-95.

Avinash KS, Ashwini HS, Babu HN \& Krishnamurthy YL (2015) Antimicrobial Potential of Crude Extract of Curvularia lunata, an Endophytic Fungi Isolated from Cymbopogon caesius. Journal of Mycology 2015: Article ID 185821.

Banu AR, Devi MK, Gnanaprabhal GR, Pradeep BV \& Palaniswamy M (2010) Production and characterization of pectinase enzyme from Penicillium chrysogenum. Indian Journal of Science and Technology 3(4): 377381.

Basumatary M, Dutta BK, Singha DM \& Das N (2015) Some in-vitro observations on the biological control of Sclerotium rolfsii, a serious pathogen of various agricultural crop plants. IOSR-Journal of Agriculture and Veterinary Science 8: 87-94.

Bowers R, Lauber C, Wiedinmyer C, Hamady M, Hallar A, Fall R, Knight R \& Fierer N (2009) Characterization of airborne microbial communities at a high-elevation site and their potential to act as atmospheric ice nuclei. Applied Environmental Microbiology 75: 5121-5130.

Bowers RM, Clements N, Emerson JB, Wiedinmyer C, Hannigan MP \& Fierer N (2013) Seasonal variability in bacterial and fungal diversity of the near-surface atmosphere. Environmental Science \& Technology 47(21): 12097-12106.

Burge HA \& Rogers CA (2000) Outdoor allergens. Environ Health Perspectives 108: 653-659.

Cabral JP (2010) Can we use indoor fungi as bioindicators of indoor air quality? Historical perspectives and open questions. Science of Total Environment 408(20): 4285-4295.

Cao C, Jiang W, Wang B, Fang J, Lang J, Tian G, Jiang J \& Zhu TF (2014) Inhalable microorganisms in Beijing's PM2.5 and PM10 pollutants during a severe smog event. Environmental Science \& Technology 48(3): 1499-1507.

de Ana SG, Torres-Rodríguez JM, Ramírez EA, García SM \& Belmonte-Soler J (2006) Seasonal distribution of Alternaria, Aspergillus, Cladosporium and Penicillium species isolated in homes of fungal allergic patients. Journal of Investigational Allergology and Clinical Immunology 16: 357-363.

Fernstrom A \& Goldblatt M (2013) Aerobiology and its role in the transmission of Infectitious diseases. Journal of Pathogens 2013: Article ID 493960.

Green JL, Holmes AJ, Westoby M, Oliver I, Briscoe D, Dangerfield M, Gillings M \& Beattie AJ (2004) Spatial scaling of microbial eukaryote diversity. Nature 432: 747-750.

Hedayati M, Mayahi S, Movahedi M \& Shokohi T (2011) Study on fungal flora of tap water as a potential reservoir of fungi in hospitals in Sari city, Iran. Journal of Medical Mycology 21(1): 10-14.

Horner WE, Worthan AG \& Morey PR (2004) Air- and dustborne mycoflora in houses free of water damage and fungal growth. Applied and Environmental Microbiology 1(70): 6394-6400.

Larsen L \& Gravesen S (1991) Seasonal variation of outdoor airborne viable microfungi in Copenhagen, Denmark. Grana 30: 467-471.

Li DW \& Kendrick B (1995) A year-round comparison of fungal spores in indoor and outdoor air. Mycologia 87(2): 190-195.

Nielsen KF (2003) Mycotoxin production by indoor molds. Fungal Genetics and Biology 39:103-177.

Pakshir K, Shekarkhar G, Mostagnie S, Sabayan B \& Vaghefikia A (2007) Monitoring of airborne fungi in two general hospitals in Shiraz, Southern Iran. Iran Journal of Medical Science 32(4): 240-244.

Shen HD, Lin WL, Tam MF, Wang SR, Tzean SS, Haung MH \& Han SH (2001) Characterization of allergens from Penicillium oxalicum and $P$. notatum by immunoblotting and $\mathrm{N}$-terminal amino acid sequence analysis. Clinical and experimental Allergy 29(5): 642-665.

Whipps JM \& Lumsden RD (2008) Biological control of Pythium species. Journal of Biocontrol Science and Technology 1(2): 75-90.

Zhang Z, Jin B \& Kelly MJ (2007) Production of lactic acid from renewable materials by Rhizopus fungi. Biochemical Engineering Journal 35: 251-263. 